\title{
Ovarian ectopic pregnancy: the role of complex morphopathological assay. Review and case presentation
}

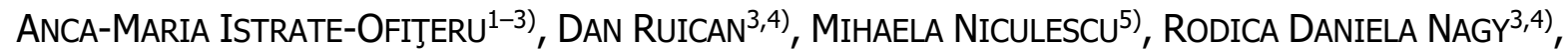 \\ GABRIELA-CAMELIA ROŞU ${ }^{1,2)}$, ANA-MARIA PETRESCU ${ }^{3)}$, ROXANA CRISTINA DRĂGUŞIN ${ }^{3}$, LARISA IOVAN ${ }^{1-4)}$, \\ GEORGE LUCIAN ZORILÄ ${ }^{3}$, DOMINIC GABRIEL ILIESCU ${ }^{3)}$
}

\author{
1) Department of Histology, University of Medicine and Pharmacy of Craiova, Romania \\ ${ }^{2)}$ Research Center for Microscopic Morphology and Immunology, University of Medicine and Pharmacy \\ of Craiova, Romania \\ 3) Department of Obstetrics and Gynecology, University of Medicine and Pharmacy of Craiova, Romania \\ 4) PhD Student, Doctoral School, University of Medicine and Pharmacy of Craiova, Romania \\ ${ }^{5)}$ Department of Anatomy, University of Medicine and Pharmacy of Craiova, Romania
}

\begin{abstract}
Ovarian ectopic pregnancy (OEP) represents the rarest type of ectopic pregnancy, accounting for $1-3 \%$ of this pathology. The diagnosis of this pathology is challenging due to the non-specific clinical aspects and the ultrasound examination hampered by the lack of visible gestational sac in the presence of hematocele and hemoperitoneum. The purpose of the extended histopathological (HP) examination was to identify particular aspects of the OEP trophoblast and to highlight potential local ovarian modifications which can determine pregnancy fixation at this level. The patient presented local favorable conditions for intraovarian nidation, conditions confirmed by the HP classical examination and by the immunohistochemical evaluation. We identified, using classical Hematoxylin-Eosin, Masson's trichrome and Periodic Acid-Schiff (PAS)-Hematoxylin, necrotic hemorrhage, accentuated vascular thrombosis and high density lymphoplasmocytary infiltrate. These modifications increased local adhesivity and cell destruction through hypoperfusion. Anti-cluster of differentiation antibodies (CD34, CD38, tryptase) revealed the low number of intravillous vessels and the high number of macrophages and mastocytes involved in the local inflammatory process heighten. We identified the presence of trophoblast tissue in the ovarian structure using anti-cytokeratin AE1/AE3 (CK AE1/AE3)/anticytokeratin 7 (CK7) antibodies. The anti-alpha-smooth muscle actin ( $\alpha$-SMA) and anti-vimentin (VIM) antibodies displayed the density of myofibroblasts and intravillous stromal cells and with the aid of anti-progesterone receptor (PR) antibody, we identified the corpus luteum hormonal response in the OEP. The placental villosities present a blocked multiplication process at the anti-apoptotic B-cell lymphoma 2 (BCL2) protein, confirmed by the Ki67 cell proliferation and tumor protein 63 (p63) immunomarkers. Anti-neuron specific enolase (NSE), anticalretinin and anti-inhibin A antibodies showed the particular aspects of the granulosa and internal theca cells, which may be involved in oocyte release blockage, intraluteal and extraluteal fecundation of the OEP.
\end{abstract}

Keywords: hemoperitoneum, laparotomy, ovarian pregnancy, pathology.

\section{口 Introduction}

Ectopic pregnancy is defined as a pregnancy implantation outside the uterine cavity. Differential diagnosis of ectopic pregnancy is important when a woman presents with abdominal or pelvic pain, genital bleeding, and positive pregnancy test [1].

Ectopic pregnancy represents a major health problem and account for $10 \%$ of total maternal deaths [2].

There are several risk factors for ectopic pregnancy: pelvic inflammatory disease (PID), history of ectopic pregnancies, Fallopian tube surgery, smoking, assisted reproduction and in vitro fertilization techniques [3].

Approximately $97-98 \%$ of extrauterine pregnancies are located in the Fallopian tubes. The ampullar portion of the tube is the most frequent location, accounting for $70 \%$ of tubal pregnancies, followed by isthmic and fimbriae level. Ovarian, uterine scar, peritoneal and cervical pregnancies add up to $3 \%$ of the total ectopic pregnancies [4].
Ovarian ectopic pregnancy (OEP) is one of the rarest types of implantation [5, 6]. The incidence of OEP varies from $1 / 2000$ to $1 / 60000$ in spontaneous pregnancies and it represents $3 \%$ of all ectopic pregnancies $[6,7]$.

\section{Aim}

The aim of this study was to determine if the detailed histopathological (HP) exam of the trophoblast can offer the possibility of identifying OEP specific elements and to emphasis potential local ovarian factors which can lead to pregnancy fixation at this site.

\section{ㅁ Pathophysiological mechanisms}

The natural course of OEP finalizes with rapture of the embryonic sac by the end of the first trimester which leads to hemoperitoneum [8]. However, there have been cases reported up to 34 weeks of gestations. In one of these, the patient presented for acute abdomen and through

This is an open-access article distributed under the terms of a Creative Commons Attribution-NonCommercial-ShareAlike 4.0 International Public License, which permits unrestricted use, adaptation, distribution and reproduction in any medium, non-commercially, provided the new creations are licensed under identical terms as the original work and the original work is properly cited. 
surgery, a live female fetus was extracted with intact amniotic membranes [9].

OEP is frequently associated with intrauterine devices (IUDs), history of ectopic pregnancies, endometriosis, Fallopian tube lesions, PID, contraceptive measures, Chlamydia infection, age, and socioeconomic factors $[10,11]$. Furthermore, some local factors can also be implicated, factors which have been observed in our case of OEP.

Previous studies showed a true rise of incidence of OEP caused by Caesarean (C)-sections [12].

Similar to other studies, the intrafollicular fertilization was caused due to failure of oocyte release after the rupture of the mature follicle [13].

Spiegelberg [14] described some criteria for OEP: the Fallopian tube of the affected side, including the fimbriae, should be intact and separated from the ovary, the gestational sac should be in the cortical section of the ovary, the ovary should be in the normal position attached to the uterine body through the utero-ovarian ligament and finally, the HP examination must demonstrate the presence of placental villosities in the ovarian cortex. Following these criteria, our case fits the complete description of OEP. The remaining ovarian tissue should help preserve normal fertility. The recurrence rate for this pathology is very rare when compared with the Fallopian ectopic pregnancy [15].

OEP etiology is not fully known but there are numerous factors which can favor the fixation of the pregnancy at the ovarian level: $(i)$ inflammation and increased local adhesivity, low intrafollicular pressure or specific modifications of the granulosa cells or the cumulus oophores cells; (ii) Fallopian tubes deficit due inflammation, tubal abortion or idiopathic; (iii) ovarian endometriosis; (iv) IUDs [6, 16-19]. There are studies which show that IUDs reduce intrauterine pregnancy rates by $99.5 \%$, by $95 \%$ Fallopian implantation but they do not reduce ovarian implantation. Moreover, it is believed that they represent a risk factor for OEP [17, 19].

The local intraovarian particularities could favor pregnancy implantation at this level.

\section{Clinical symptoms}

The clinical aspect of OEP is represented by pelvic or abdominal pain ranging from medium to severe intensity, vaginal bleeding, and a positive pregnancy test.

OEP is an acute pathology in $90 \%$ of cases. Some ectopic tubal pregnancies treated with Methotrexate, without laparoscopic confirmations can be misdiagnosed OEP [20]. The high value of beta human chorionic gonadotropin $(\beta \mathrm{hCG})$, amenorrhea and the acute abdominal and pelvic symptomatology, and the palpation of painful adnexal mass determined the therapeutic management of OEP [21, 22].

\section{Ultrasound examination}

Ultrasonography is a routinely imagistic examination performed when an ectopic pregnancy is suspected. Ideally, patients are scanned transabdominal, with a full urinary bladder and transvaginal. The transabdominal approach offers a wide field of view of the pelvis and can better visualize the uterine fundus as well as high situated adnexa [1].

The ultrasound (US) examination could not differentiate a tubal from an OEP or a possible ruptured cyst. US examination highlighted the uterus surrounded by peritoneal content, with the appearance of free clear fluid posteriorly and complex mass with coarse echoes, suggesting hematocele, in front of the uterus. The thickened decidualized endometrium was also noted. Free clear fluid and dense free fluid surrounding the uterus suggested a significant hemoperitoneum. An irregular heterogenous mass projecting from the ovary contour could also be observed, with hypodense content, communicating with the peritoneal free fluid.

When $\beta$ hCG levels are above normal values and an intrauterine pregnancy cannot be detected, an ectopic pregnancy or a $\beta$ hCG secreting source should be considered. Both adnexa should be thoroughly examined as the sings are variable and may be subtle. A normal US examination does not exclude and ectopic pregnancy. Approximately $15-35 \%$ of extrauterine pregnancies are not represented by an identifiable US mass [23]. In these situations, careful patient follow-up is required with subsequent $\beta \mathrm{hCG}$ determinations and US examinations.

\section{ㅁ Positive and differential diagnosis}

The open surgery confirmed the presence of hemoperitoneum and the ovarian ruptured mass. An advantage of this localization, as opposed to a tubal pregnancy, is represented by the possibility of fertility conservation by preserving the tube and salvaging the ovarian tissue as much as possible [15].

$\beta$ hCG levels, the quality of the US images and medical experience have a major impact on the diagnosis [21], however, due to the acute nature of the pathology, the presurgical diagnosis is of lesser significance. Thus, the differential diagnosis is made surgically and histopathologically confirmed [21, 24-27].

Differential diagnosis of OEP can be made with Fallopian tube ectopic pregnancy, hemorrhagic luteal cyst, appendicitis with early pregnancy, urinary tract infection, choriocarcinoma, ovarian tumor secreting $\beta \mathrm{hCG}$ (including dysgerminoma and seminoma) [28]. However, transvaginal US examination may be able establish the diagnosis of intact OEP [29]. This diagnosis is hard to determine in cases of complications, when hemoperitoneum or blood cloths overlay with the adnexal structures making it difficult to precisely delimitate them. In turns, OEP is suspicioned during surgery and later confirmed at the HP examination [6].

The differential diagnosis is difficult when performing and US examination. OEP, corpus luteum, hemorrhagic cyst, ruptured Fallopian pregnancy are hard to differentiate in the absence of an obvious gestational sac especially in the presence of hemoperitoneum and hematocele, which can envelope the adnexa [30].

As we mentioned above, the definitive diagnosis is done by HP examination, which confirms the clinical and surgical suspicions. 


\section{Histopathological and immunohistochemical examinations}

Histopathologically-confirmed OEP can be classified as intrafollicular or extrafollicular, the second form having two subtypes, however the clinical implication is controverted [31].

This examination confirmed the presence of bitrophoblastic mesenchymal placental villosities, with the exterior syncytiotrophoblast and interior cytotrophoblast, using the classical histological staining. This confirms the intraovarian localization of the gestational sac.

\section{ㅁ Treatment}

There are multiple surgical approaches to this pathology like total ovariectomy or partial ovariectomy [20]. There are cases in the literature where adnexectomy was performed due to the low viability of the remaining ovarian tissue [13]. In some cases, etoposides or methotrexate were not used due to the constant decrease of $\beta$ HCG levels after surgery $[13,32]$.
Management of the pathology implies surgical intervention, as follows: for moderate bleeding partial ovariectomy is recommended and full ovariectomy for massive bleeding. In cases of intact OEP, Methotrexate can be administered as a non-invasive alternative treatment [33].

\section{ㅁ Case presentation}

A 33-year-old patient presented in the Emergency Room for acute abdominal and pelvic pain, especially in the left iliac fossa. The debut occurred four hours prior to her presentation, with progressive intensification. These symptoms were accompanied by dizziness and cold sweats, which debuted four hours prior to her admittance. The blood sampled revealed: hemoglobin $12.18 \mathrm{~g} / \mathrm{dL}$, hematocrit $39.37 \%$, platelets $269.2 \times 10^{3} / \mu \mathrm{L}$, normal clothing values and a high value of $\beta$ hCG (Table 1$)$. Her obstetrical history consisted of one term birth through C-section in 2008 and two abortions on demand and her last menstrual period was 7-8 weeks before.

Table 1 - The BhCG values obtained

\begin{tabular}{|c|c|c|c|c|}
\hline \multicolumn{2}{|c|}{$\begin{array}{c}\text { Normal value in the absence } \\
\text { of pregnancy }\end{array}$} & $\begin{array}{c}\text { The preoperatory value } \\
\text { obtained }\end{array}$ & $\begin{array}{l}\text { The postoperatory value } \\
\text { obtained after } 24 \text { hours }\end{array}$ & $\begin{array}{l}\text { The postoperatory value } \\
\text { obtained at over } 72 \text { hours }\end{array}$ \\
\hline $\begin{array}{l}\text { Premenopausal } \\
<5.3 \mathrm{mlU} / \mathrm{mL}\end{array}$ & $\begin{array}{l}\text { Postmenopausal } \\
<8.3 \mathrm{mIU} / \mathrm{mL}\end{array}$ & $6025 \mathrm{mIU} / \mathrm{mL}$ & $1915 \mathrm{mlU} / \mathrm{mL}$ & $588.0 \mathrm{mlU} / \mathrm{mL}$ \\
\hline
\end{tabular}

$\beta$ hCG: Beta human chorionic gonadotropin.

After blood samples were collected, an US transvaginal examination was performed.

The US examination revealed the uterus surrounded by peritoneal content, with the appearance of free clear fluid posteriorly and complex mass with coarse echoes, suggesting hematocele, in front of the uterus and decidualized endometrium (Figure 1A). Furthermore, we observed free clear fluid and dense free fluid surrounding the uterus, suggesting a significant amount of hemoperitoneum (Figure 1B) and irregular heterogenous mass projecting from the left ovary contour, with hypodense content and communicating with the peritoneal free fluid (Figure 1, C and D).

Surgical treatment was elected. Pfannenstiel laparotomy was performed and massive hemoperitoneum was observed. After lavage, we noticed a left ovary lesion with adherent cloths. The cloths were removed and the left adnexa was exteriorized. The left Fallopian tube had a normal aspect. The ovary presented an eccentric, violaceous, crateriform formation (Figure 2B). Partial ovariectomy was performed and the formation was excised (Figure 2C). Ovarian suture was performed at this site (Figure 2D). The right ovary and Fallopian tube were normal (Figure 2E). The extracted tissue was sent for HP examination (Figure 2F). Postoperatively, the $\beta$ hCG level was $1915 \mathrm{mIU} / \mathrm{mL}$, with subsequent lower levels in the following days (Table 1). The patient underwent antibiotic, anticoagulant, pain countering treatment with a good outcome and was discharged four days after the intervention. The case was followed up accordingly.

The fragment was sent to the Department of Pathology for investigations and was prepared in the Research
Center for Microscopic Morphology and Immunology, University of Medicine and Pharmacy of Craiova, Romania. The whole tissue was fixed in $10 \%$ neutral buffered formalin and routinely processed for paraffin embedding (FFPE). The block was sectioned at $5 \mu \mathrm{m}$ with the aid of a HM350 microtome equipped with a section transfer to water bath system. (STS microM). The sections have been stained using classical HematoxylinEosin (HE), Masson's trichrome (MT), Periodic AcidSchiff-Hematoxylin (PAS-H) on poly-L-lysine covered slides. The slides were deparaffinized, rehydrated with successive alcohol baths with decreasing concentration of $100 \%, 96 \%, 90 \%, 70 \%$ (5 minutes each) and then with distilled water $\left(\mathrm{dH}_{2} \mathrm{O}\right)$ for 15 minutes.

The immunohistochemical (IHC) techniques involved antigenic exposure, performed with citrate $\mathrm{pH} 6$ or with ethylenediaminetetraacetic acid (EDTA) $\mathrm{pH}$ 9, endogenous peroxidase deactivation with the aid of $3 \%$ hydrogen peroxide $\left(\mathrm{H}_{2} \mathrm{O}_{2}\right)$ (30 minutes), non-specific endogenous situses blockage with skim milk (30 minutes). After these procedures, the primary antibody was applied (Table 2) and the slides were kept at $4^{\circ} \mathrm{C}$ (for 18 hours). The second antibody was applied the following day [mouse/rabbit immunoglobulin G (IgG) antibody, VC002-025, R\&D Systems, VisUCyte Horseradish peroxidase (HRP) Polymer] (one hour). The slides underwent development with the aid of 3,3'-Diaminobenzidine (DAB) (Dako) and the nuclei were marked with a Hematoxylin solution. In the end, the slides were dehydrated with increasing concentration of alcohol 70\%, 90\%, 96\%, 100\% (5 minutes each), clarified in three successful xylene baths $(3 \times 15$ minutes/bath $)$ and a slide was fixed on the tissue using Canada balm. 

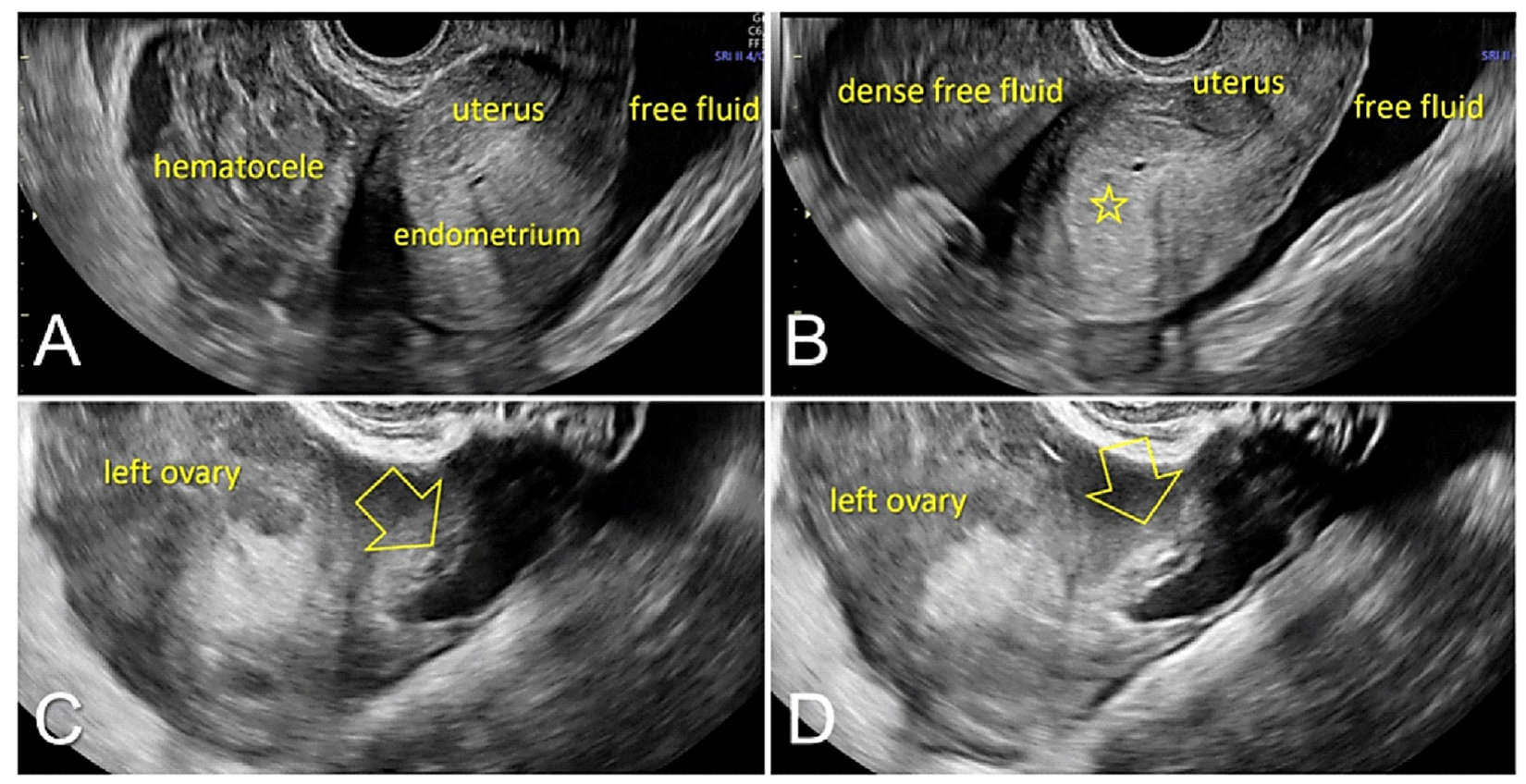

Figure 1 - Ultrasound assessment during the consultation in the Emergency Room: (A) Uterus surrounded by peritoneal content, with the appearance of free clear fluid posteriorly and complex mass with coarse echoes, suggesting hematocele, in front of the uterus - note the thickened decidualized endometrium (open star); (B) Free clear fluid and dense free fluid surrounding the uterus, suggesting a significant amount of hemoperitoneum; (C and D) Irregular heterogenous mass (open arrow) projecting from the left ovary contour, with hypodense content and communicating with the peritoneal free fluid.
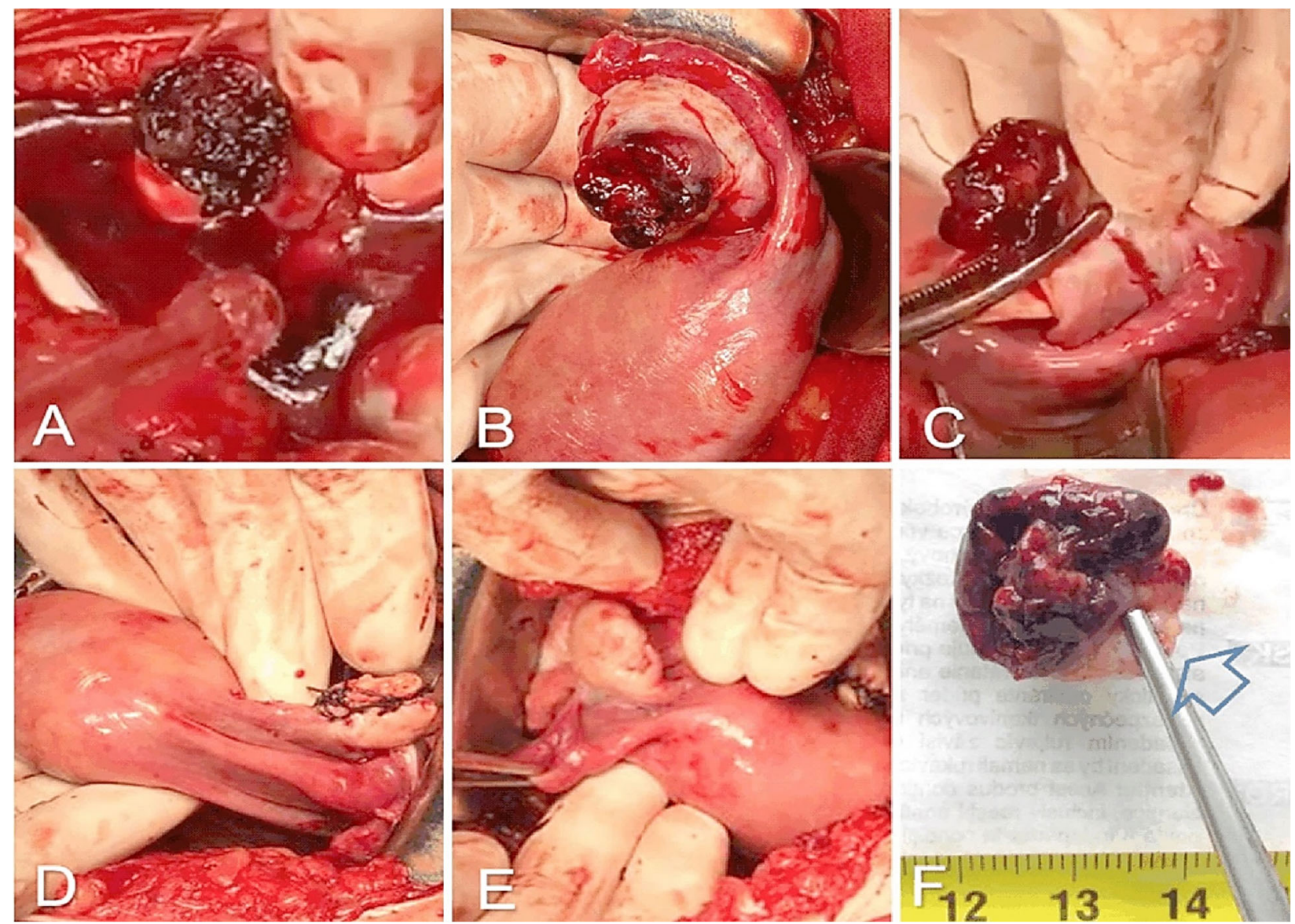

Figure 2 - Intraoperative images: (A) Massive hemoperitoneum and left ovary solution of continuity with adherent clots, continuing with the hematocele; (B) Exteriorization of left adnexa after the aspiration of the blood and clots normal left uterine tube and left ovary with a violaceus, eccentric mass, covered with adherent cloths and a large, crateriform solution of contiguity; (C) The ovary is clamped in healthy tissue, the mass is excised with safety margins; (D) Interrupted suture at excision level; (E) Right tube and ovary with normal appearance; $(F)$ The excised ovarian tissue with an area of healthy margin marked with an arrow. (G) Postoperative macroscopic aspects. 
Ovarian ectopic pregnancy: the role of complex morphopathological assay. Review and case presentation

Table 2 - Immunohistochemical panel of antibodies used by us

\begin{tabular}{|c|c|c|c|c|c|c|}
\hline Antibody & Manufacturer & Clone & Antigenic exposure & Secondary antibody & Dilution & Labeling \\
\hline Anti-CK7 & Dako & OV-TL 12/30 & Citrate, $\mathrm{pH} 6$ & $\begin{array}{l}\text { Monoclonal mouse } \\
\text { anti-human CK7 }\end{array}$ & $1: 50$ & Glandular epithelia \\
\hline $\begin{array}{c}\text { Anti-CK } \\
\text { AE1/AE3 }\end{array}$ & Dako & AE1/AE3 & Citrate, $\mathrm{pH} 6$ & $\begin{array}{c}\text { Monoclonal mouse } \\
\text { anti-human CK }\end{array}$ & $1: 50$ & Epithelial tissues \\
\hline Anti-CD34 & Dako & QBEnd/10 & Citrate, $\mathrm{pH} 6$ & $\begin{array}{l}\text { Monoclonal mouse anti- } \\
\text { human CD34 Class II }\end{array}$ & $1: 50$ & $\begin{array}{l}\text { Neoformed blood } \\
\text { vessels }\end{array}$ \\
\hline Anti- $\alpha-S M A$ & Dako & $1 \mathrm{~A} 4$ & Citrate, $\mathrm{pH} 6$ & $\begin{array}{c}\text { Monoclonal mouse } \\
\text { anti-human SMA }\end{array}$ & $1: 100$ & $\begin{array}{l}\text { Alpha-smooth muscle } \\
\text { actin }\end{array}$ \\
\hline Anti-VIM & Dako & V9 & Citrate, $\mathrm{pH} 6$ & $\begin{array}{c}\text { Monoclonal mouse } \\
\text { anti-vimentin }\end{array}$ & $1: 50$ & Mesenchymal cells \\
\hline Anti-ER & Dako & 1D5 & EDTA, pH 9 & $\begin{array}{l}\text { Monoclonal mouse } \\
\text { anti-human ER } \alpha\end{array}$ & $1: 50$ & $\begin{array}{c}\text { Estrogen receptor } \\
\text { alpha }\end{array}$ \\
\hline Anti-PR & Dako & PgR 636 & EDTA, pH 9 & $\begin{array}{l}\text { Monoclonal mouse } \\
\text { anti-human PR }\end{array}$ & $1: 50$ & Progesterone receptor \\
\hline Anti-Ki67 & Dako & MIB-1 & EDTA, pH 9 & $\begin{array}{l}\text { Monoclonal mouse } \\
\text { anti-human Ki67 }\end{array}$ & $1: 50$ & $\begin{array}{l}\text { Cells in division in the } \\
\mathrm{G} 1, \mathrm{~S}, \mathrm{G} 2 \text { and } \mathrm{M} \text { phase }\end{array}$ \\
\hline Anti-p63 & Dako & $4 \mathrm{~A} 4$ & Citrate, $\mathrm{pH} 6$ & $\begin{array}{l}\text { Monoclonal mouse anti- } \\
\text { human p63 protein }\end{array}$ & $1: 50$ & Nuclear marker \\
\hline Anti-p53 & Dako & DO-7 & EDTA, pH 9 & $\begin{array}{l}\text { Monoclonal mouse anti- } \\
\text { human p53 protein }\end{array}$ & $1: 50$ & Nuclear marker \\
\hline Anti-BCL2 & Dako & 124 & EDTA, pH 9 & $\begin{array}{l}\text { Monoclonal mouse anti- } \\
\text { human BCL2 oncoprotein }\end{array}$ & $1: 50$ & B-cell lymphoma 2 \\
\hline Anti-CD68 & Dako & KP1 & Citrate, $\mathrm{pH} 6$ & $\begin{array}{c}\text { Monoclonal mouse } \\
\text { anti-human CD68 }\end{array}$ & $1: 100$ & Macrophages \\
\hline Anti-tryptase & Dako & AA1 & Citrate, $\mathrm{pH} 6$ & $\begin{array}{l}\text { Monoclonal mouse anti- } \\
\text { human mast cell tryptase }\end{array}$ & $1: 500$ & Mast cells \\
\hline Anti-calretinin & Dako & Dak-Calret 1 & EDTA, pH 9 & $\begin{array}{l}\text { Monoclonal mouse } \\
\text { anti-human calretinin }\end{array}$ & $1: 50$ & Mesothelial tissue \\
\hline Anti-NSE & Dako & $\begin{array}{l}\text { BBS/NC/ } \\
\text { VI-H14 }\end{array}$ & Citrate, $\mathrm{pH} 6$ & $\begin{array}{l}\text { Monoclonal mouse } \\
\text { anti-human NSE }\end{array}$ & $1: 100$ & $\begin{array}{c}\text { Neuronal cells and cells } \\
\text { with neuroendocrine } \\
\text { differentiation }\end{array}$ \\
\hline
\end{tabular}

a-SMA: Alpha-smooth muscle actin; BCL2: B-cell lymphoma 2; CD: Cluster of differentiation; CK: Cytokeratin; EDTA: Ethylenediaminetetraacetic acid; ER: Estrogen receptor; NSE: Neuron-specific enolase; p53: Tumor protein 53; p63: Tumor protein 63; PR: Progesterone receptor; VIM: Vimentin.

The ovarian sample was examined at the microscope and, with the aid of the classical HE staining, trophoblastic mesenchymal villosities with external syncytiotrophoblast and internal cytotrophoblast were observed. It presented atypical hypercellularity with hypovascularity for its gestational age (Figure 3A).

Moreover, we identified a necrotic hemorrhagic zone and the presence of extravillous interstitial trophoblast and extravillous gigantocellular trophoblast (Figure 3B). Pregnancy corpus luteum was identified with periluteal and intraluteal inflammatory lymphoplasmocytary elements (Figure 4A) and some of these villosities presented polar trophoblastic proliferation. Generally, at this gestational age, the villosities have a hypocellular, hypervascular aspect. Some thrombophilia modifications can be suspected due to the necrotic hemorrhagic zone in the extravillous trophoblastic area. The ovary structure contained clogged vessels with well represented vascular wall, hemorrhagic necrosis, perivascular lymphoplasmocytary infiltration, thecal cells and extravillous interstitial and gigantocellular trophoblast (Figure 5B). Thecal cells with polygonal aspect can be identified surrounding the granulosa cells (Figure $5 \mathrm{C}$ ).

We emphasized the granulosa cells with the aid of IHC anti-cytokeratin AE1/AE3 (CK AE1/AE3) antibody, usually positive at the cytoplasmatic level and extravillous extracellular gigantocellular trophoblast (Figure 6, A and B). Positive reaction was obtained using the anti-cytokeratin 7 (CK7) antibody at the intracytoplasmatic level of the cytotrophoblast and negative reaction at the syncytiotrophoblast (Figure 7A). Anti-cluster of differentiation 34 (CD34) antibody revealed weak vascularization of placental mesenchymal bitrophoblastic villosities, with marginal vascularity specific for early pregnancy, and at the granulosa level the reaction was positive for endothelial vascular cells (Figure 7B).

Anti-alpha-smooth muscle actin ( $\alpha$-SMA) antibody revealed another actin present in the granulosa myofibroblast cells, and the sheath was intensely positive (Figure 8A). We marked the mesenchymal cells from the mesenchymal placental villosities with anti-vimentin (VIM) antibody and we noticed the incredible high number of these cells and of the positive marked granulosa cells (Figure8B). Regarding the hormone receptors, the antiestrogen receptor alpha $(\mathrm{ER} \alpha)$ antibody immunoreaction was negative and the immunoreaction with the antiprogesterone receptor (PR) antibody was slightly positive at the sheath cells which still produce progesterone. Granulosa cells were positive for anti-PR antibody and the reaction was negative for the mesenchymal placental villosities (Figure 9). The cytotrophoblast was positive for anti-Ki67 antibody and for the anti-tumor protein 63 (p63) antibody (Figure 10, A and B). The bitrophoblast villosities were negative for $\mathrm{p} 63$ antibody but positive for anti-B-cell lymphoma 2 (BCL2) antibody, especially at the syncytiotrophoblast level (Figure 11A). With the aid of anti-neuron-specific enolase (NSE) antibody, we obtained a positive immunoreaction at the extravillous interstitial and gigantocellular trophoblast and at the endocrine secretion granulosa cells (Figure 11B). We identified macrophages and mastocytes at the extravillous interstitial trophoblast using anti-cluster of differentiation 68 (CD68) and anti-tryptase antibodies, respectively, cells which have an important role in the inflammation process (Figure 12, A and B). Anti-calretinin antibody emphasized individual 
stromal cells and sheath individual luteinizing cells but the granulosa and external sheath cells were negative (Figure 13A). Sheath cells were positive and granulosa cells were negative for anti-inhibin antibody (Figure 13B).

The originality of this paper lies in the emphasis of

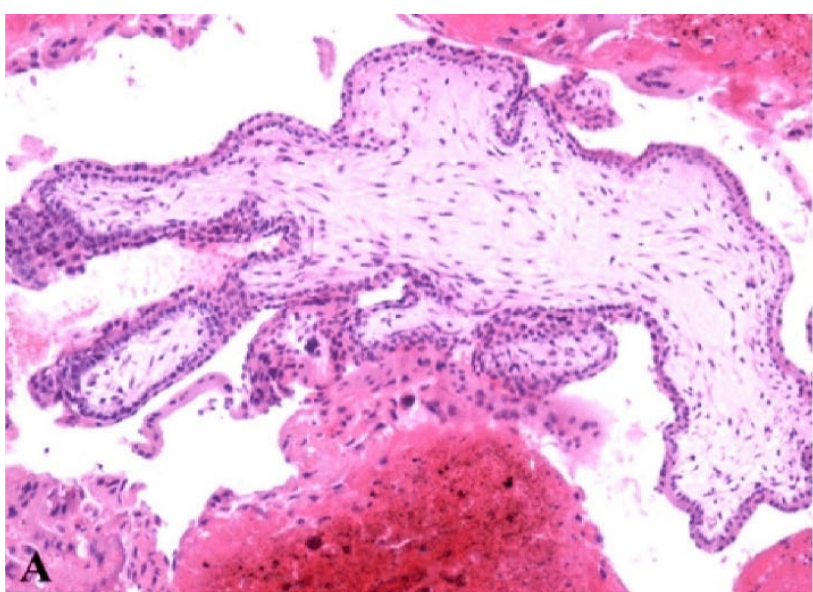

particular elements which may represent causes of intraovarian fecundation. The HP aspects are strengthened by the history and clinical aspects of the case. By highlighting potential risk factors, patient counselling can be improved as well as case prenatal management.

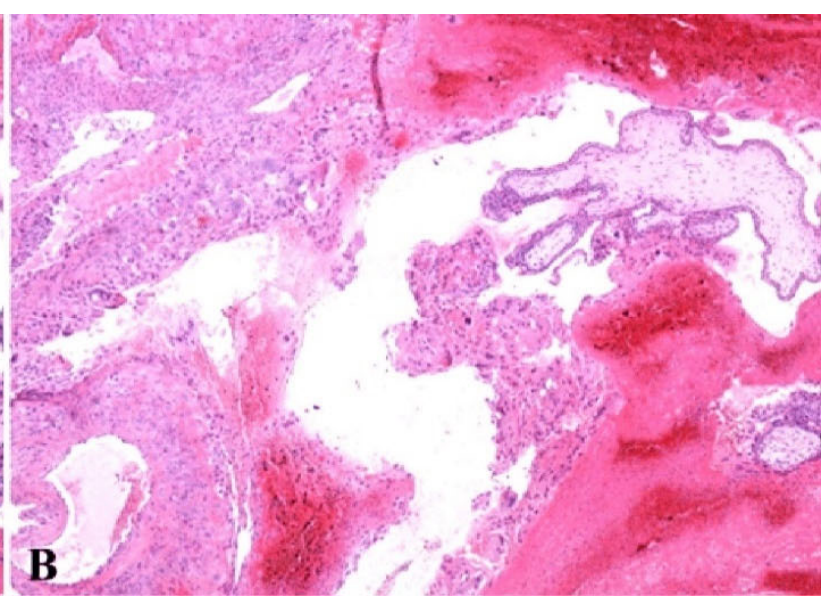

Figure 3 - (A) Bitrophoblastic mesenchymal placental villi with syncytiotrophoblast on the outside and cytotrophoblast on the inside, with hypercellular and hypovascular appearance; (B) Hemorrhagic necrosis and extravillous diffuse interstitial and gigantocellular trophoblast. Classical Hematoxylin-Eosin (HE) staining: $(A) \times 100 ;(B) \times 40$.

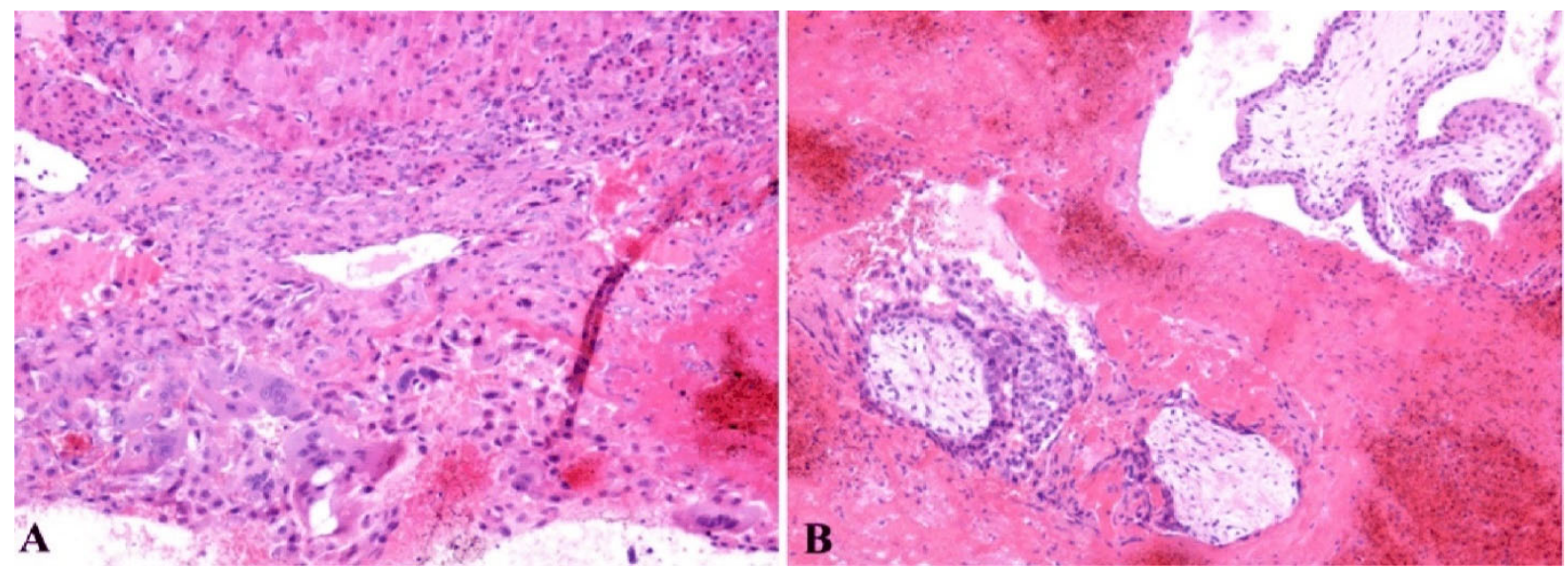

Figure 4 - (A) Extravillous gigantocellular and interstitial trophoblast at the bottom of the image, and at the top of the image, luteal cells and periluteal and intraluteal lymphoplasmocytary inflammatory cells; (B) Extravillous trophoblast, mesenchymal young bitrophoblastic villosities and at the bottom of the image a partial denudated by cytotrophoblast and syncytiotrophoblast hypocellular/hypovascular villosity - in the bottom left, image presents a trophoblastic polar proliferation. Classical Hematoxylin-Eosin $(H E)$ staining: $(A$ and $B) \times 100$.
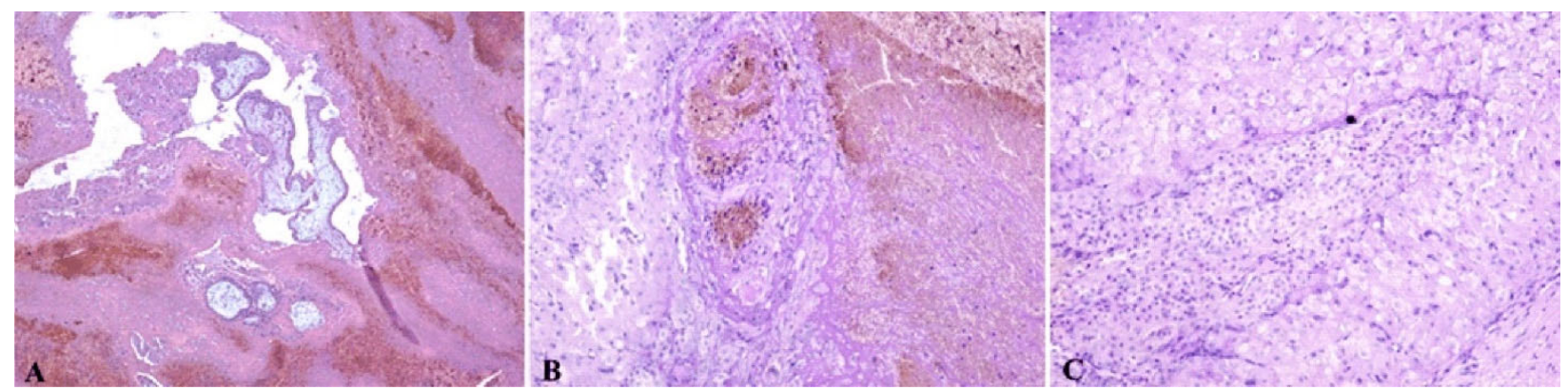

Figure 5 - (A) Extravillous trophoblast, mesenchymal young bitrophoblastic villosities and in the bottom part of the image a partial denudated by cytotrophoblast and syncytiotrophoblast hypocellular/hypovascular villosity - the bottom left part of the image presents a trophoblastic polar proliferation; extravillous trophoblast with extensive areas of hemorrhagic necrosis cand be observed; this can be explained by changes caused by thrombophilia and possible intravascular disseminated coagulation; (B) Thrombosed vessels and perivascular lymphoplasmacytic infiltrate - in the right part of the image is observed an area of hemorrhagic necrosis and in the left part thecal layer of corpus luteum; (C) In the center of the image are identified granular cells and in the periphery of the image, around the granular cells, polygonal cells representing the sheath of the ovary. Classical Masson's trichrome (MT) staining: (A) $\times 40$. Periodic Acid-SchiffHematoxylin (PAS-H) staining: (B and C) $\times 100$. 


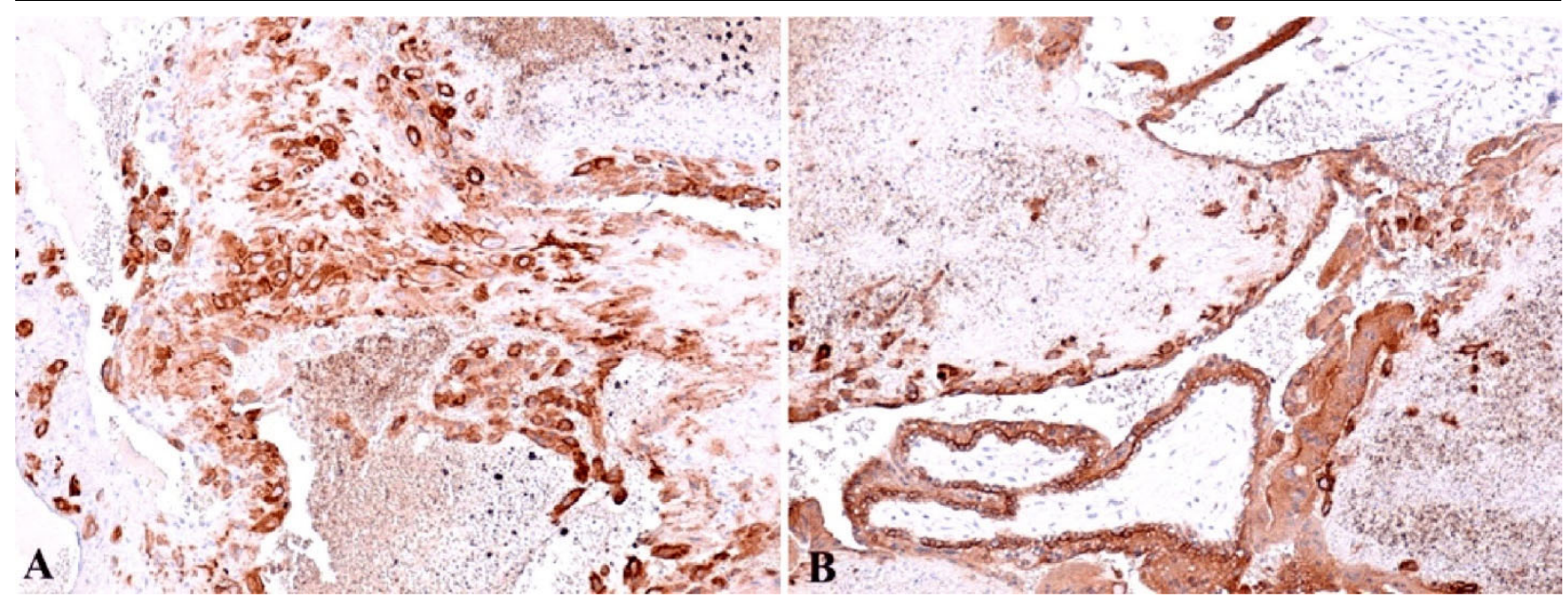

Figure 6 - (A) Granular cells disorganized by the hemorrhagic area, usually positive at cytoplasmatic level; (B) The positive reaction at extracellular extravillous gigantocellular and bitrophoblastic villous trophoblastic level. IHC staining with anti-CK AE1/AE3 antibody: (A and B) ×100. CK AE1/AE3: Cytokeratin AE1/AE3; IHC: Immunohistochemical.

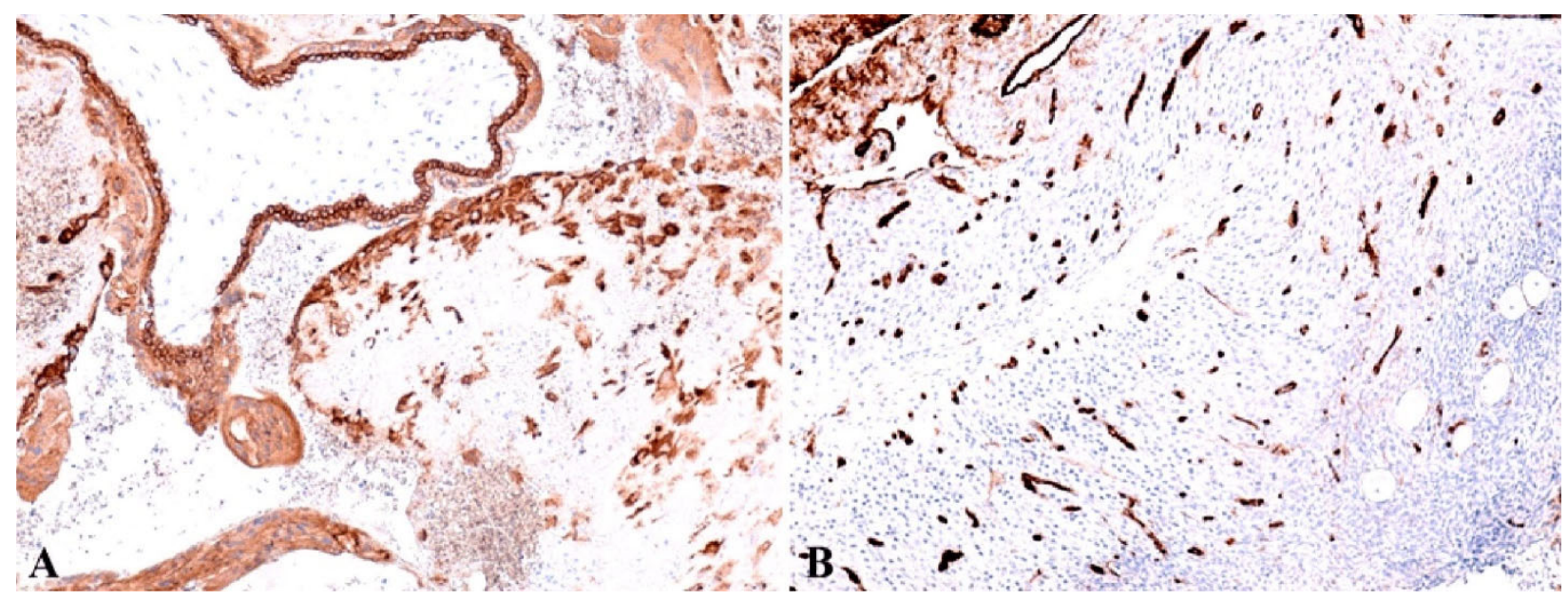

Figure 7 - (A) Positive cytotrophoblast intracytoplasmic reaction and negative at syncytiotrophoblast level-this positive result represents a factor that confirms the ovarian localization of the extrauterine pregnancy; positive reaction at granular cell lever, disorganized by the hemorrhagic necrosis; (B) Positive reaction at the corpus luteum level, in the endothelial vascular cells - corpus luteum is situated in the middle of the image, the granular and luteinized thecal cells present rare killer (K) cells at the demarcation between the two layers. IHC staining with anti-CK 7 antibody: $(A) \times 100$. IHC staining with anti-CD34 antibody: (A) $\times 100$. CD: Cluster of differentiation; CK7: Cytokeratin 7; IHC: Immunohistochemical.

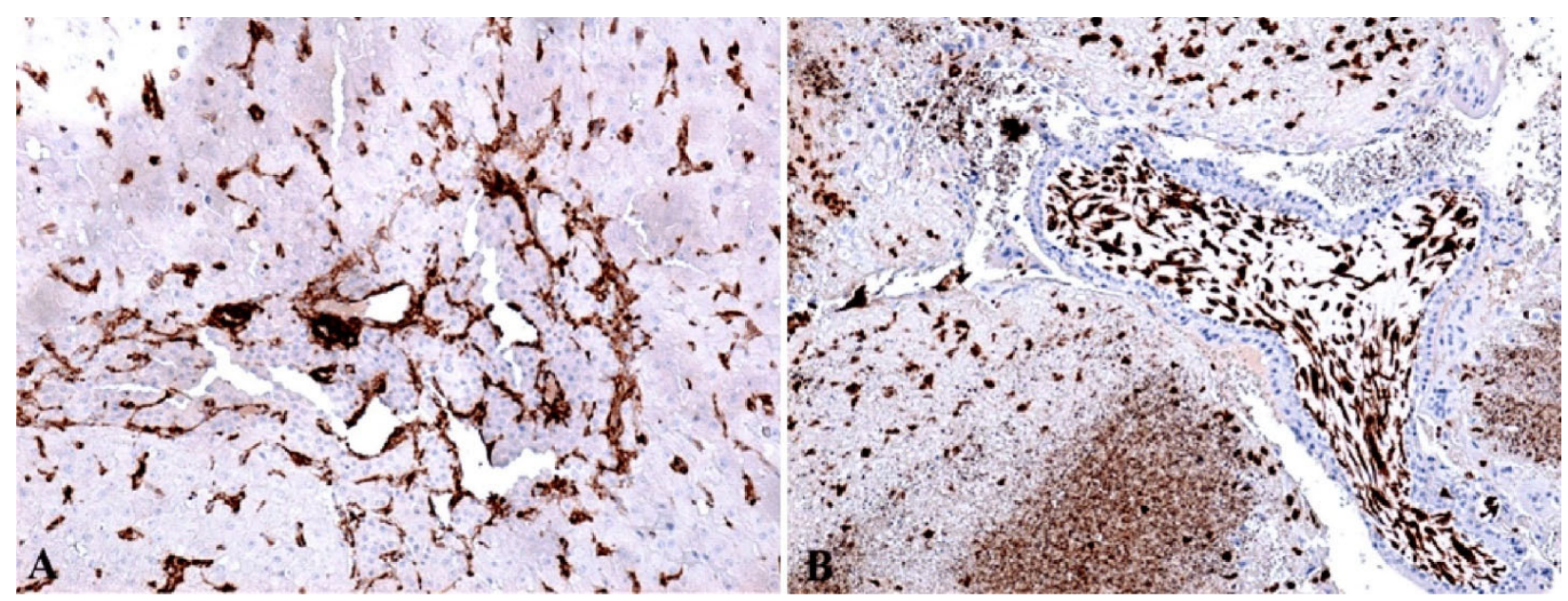

Figure 8 - (A) Focal positive reaction in the sheath of the corpus luteum and highly positive in the granulosa; (B) Highly positive mesenchymal cells inside the young or mesenchymal placental villi, but also in areas of hemorrhagic necrosis. IHC staining with anti- $\alpha-S M A$ antibody: $(A) \times 100$. IHC staining with anti-VIM antibody: $(B) \times 100 . \alpha-S M A$ : Alpha-smooth muscle actin; IHC: Immunohistochemical; VIM: Vimentin. 


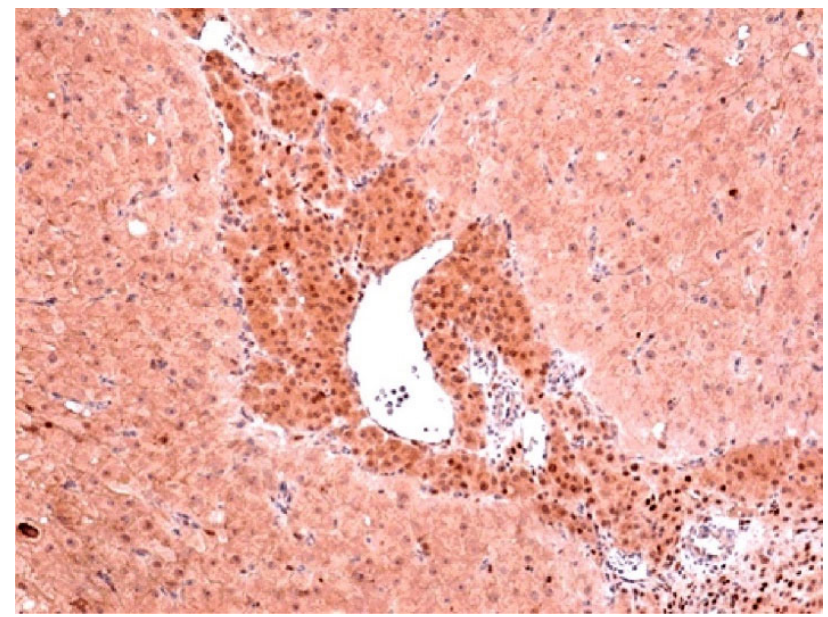

Figure 9 - Weak positive reaction in periphery thecal cells and intense positive reaction in granular cells located centrally. The reaction is negative in the mesenchymal placental villi weakly positive. IHC staining with antiPR antibody, $\times 100$. IHC: Immunohistochemical; PR: Progesterone receptor.

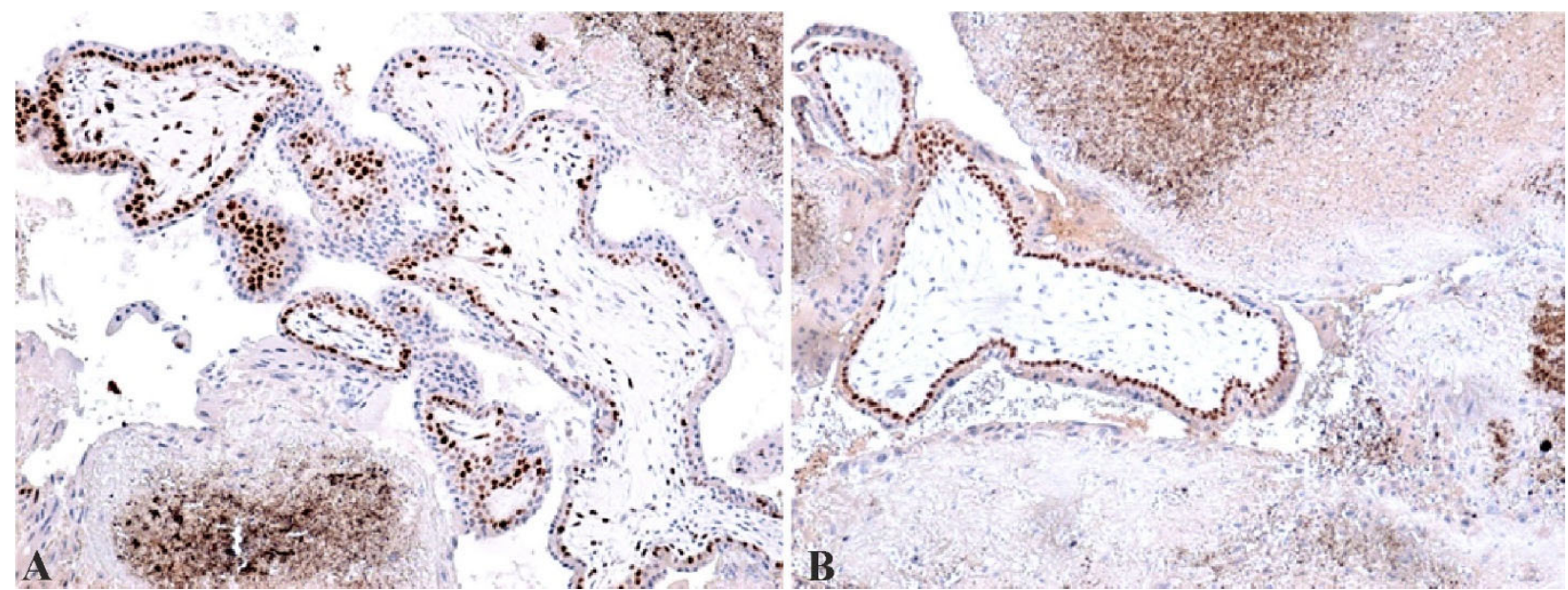

Figure 10 - (A) Positive reaction in cytotrophoblastic cells and negative reaction in syncytiotrophoblast cells; (B) Positive reaction at nuclear level in cytotrophoblast cells and negative reaction at nuclear level in syncytiotrophoblast cells. IHC staining with anti-Ki67 antibody: $($ A) $\times 100$. IHC staining with anti-p63 antibody: $(B) \times 100$. IHC: Immunohistochemical; p63: Tumor protein 63.

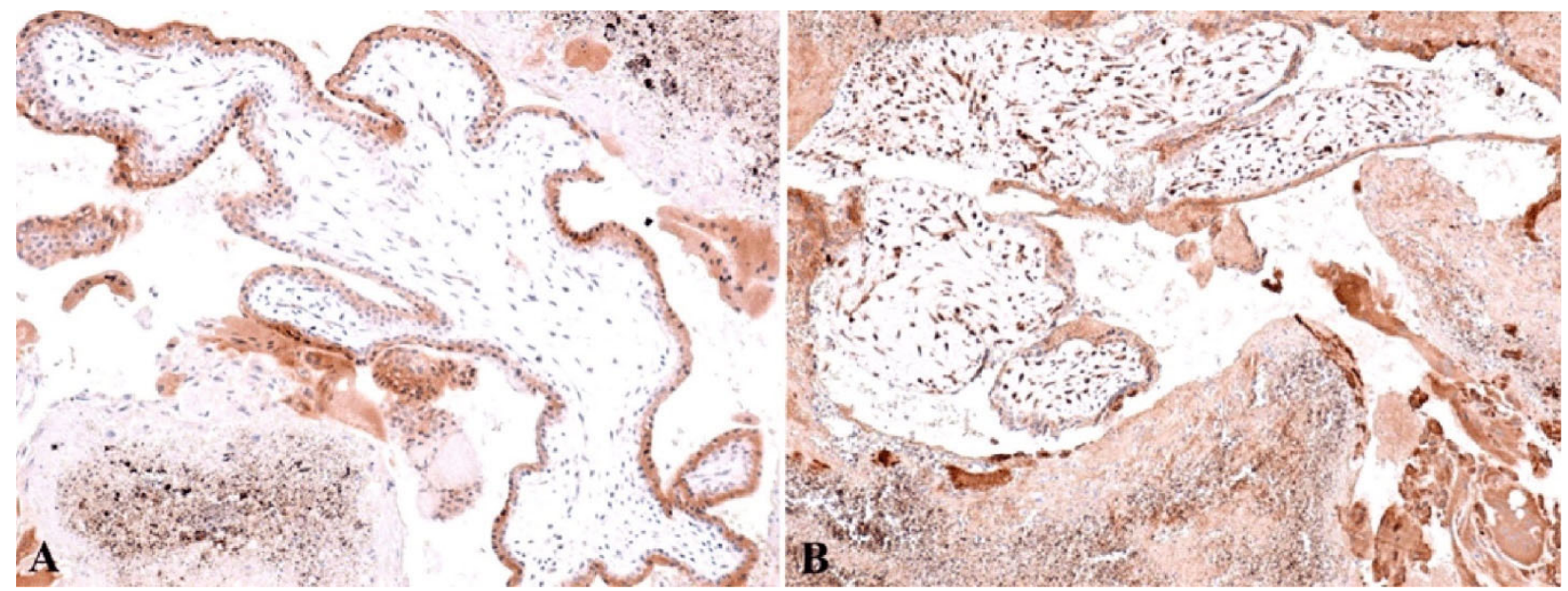

Figure 11 - (A) Positive reaction at the level of the syncytiotrophoblast, which confirms that during villous evolution the cytotrophoblast will disappear through apoptosis; (B) Positive reaction at the level of the interstitial and gigantocellular extravillous trophoblast and luteal cells. IHC staining with anti-NSE antibody: $(A) \times 100$. IHC staining with anti-BCL2 antibody: (B) $\times 100$. BCL2: B-cell lymphoma 2; IHC: Immunohistochemical; NSE: Neuron-specific enolase. 


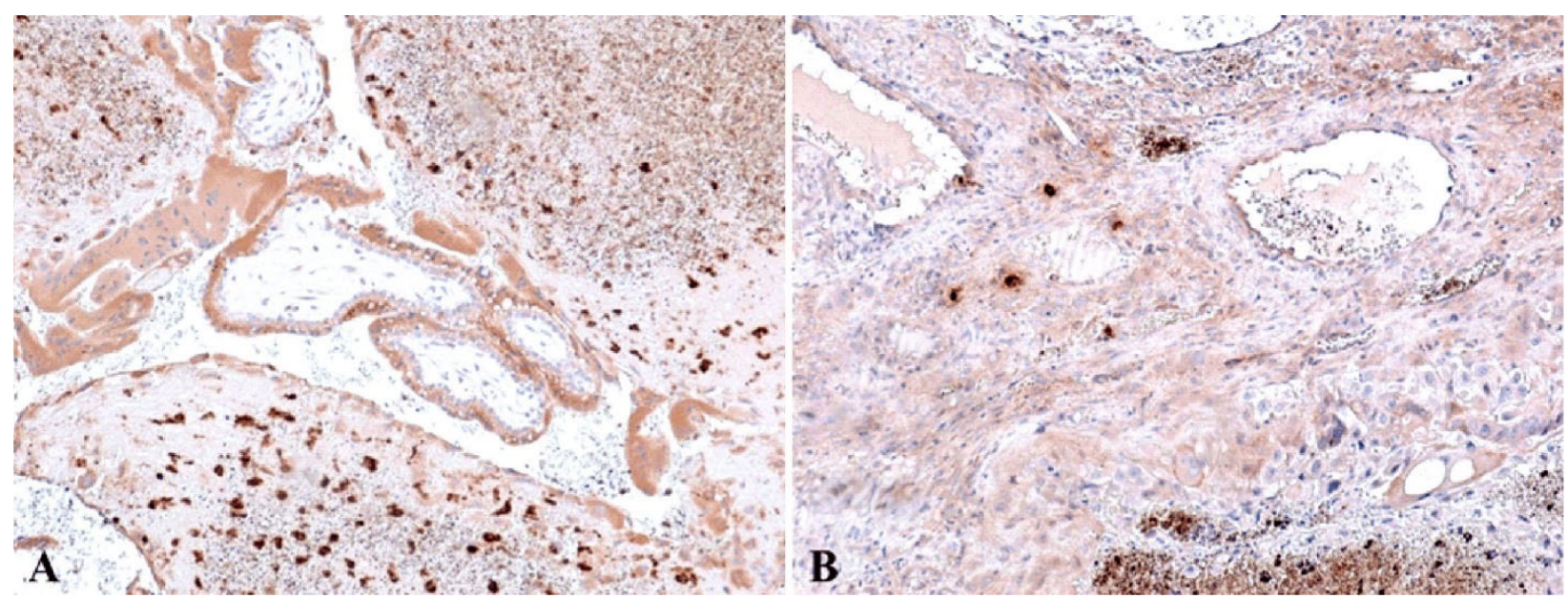

Figure 12 - (A) Positive reaction for macrophages at interstitial extravillous trophoblast level; (B) Positive reaction for mastocytes, arranged predominantly perivascular. IHC staining with anti-CD68 antibody: $(A) \times 100$. IHC staining with anti-tryptase antibody: $(B) \times 100$. CD68: Cluster of differentiation 68; IHC: Immunohistochemical.

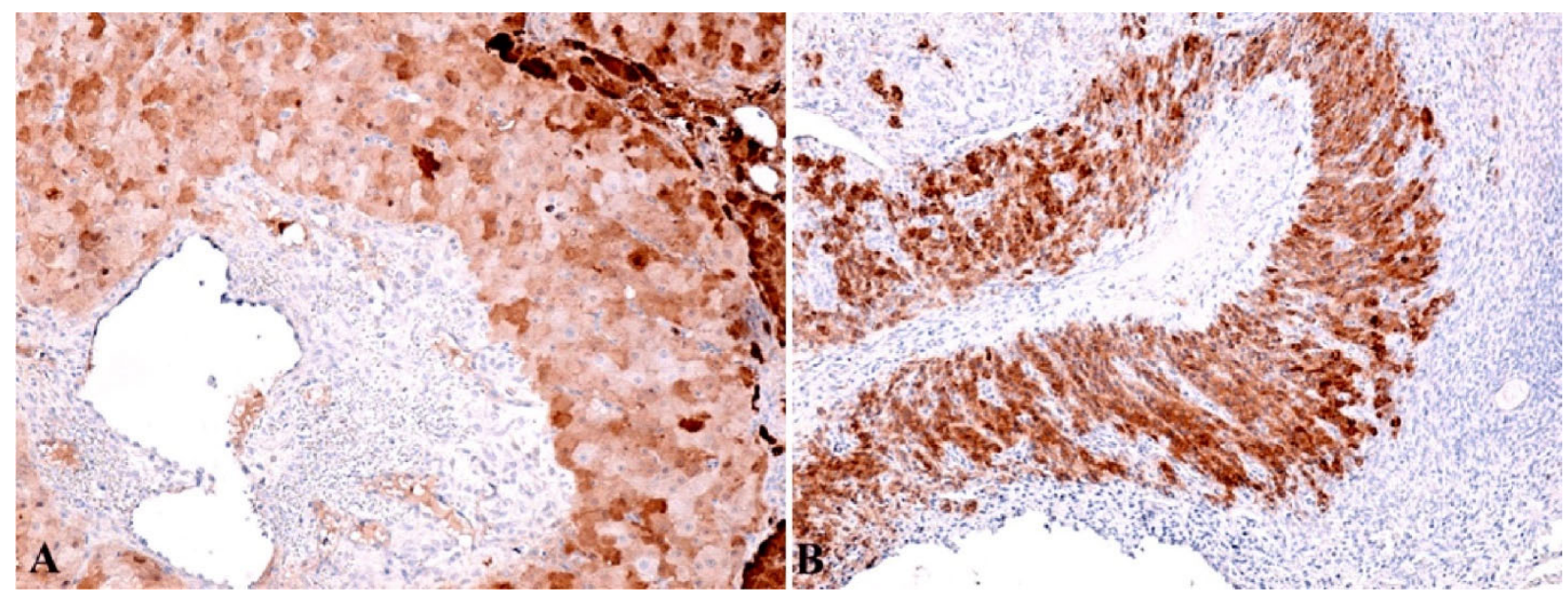

Figure 13 - (A) Positive reaction for individual stromal cells, luteinized internal thecal cells and negative reaction for granular cells and external thecal cells; (B) Positive reaction for thecal cells and negative reaction for central granular cells. IHC staining with anti-calretinin antibody: $(A) \times 100$. IHC staining with anti-inhibin antibody: $(B) \times 100$. IHC: Immunohistochemical.

\section{Discussions}

There are many causes of OEP: IUDs, endometriosis, Fallopian tube lesions, history of ectopic pregnancies, PID, contraceptive measures, infections, age, and socioeconomic factors $[10,11]$. Furthermore, some local factors can also be implicated, factors which have been observed in our case of OEP.

One of the risk factors found in our study, involved in the occurrence of OEP, was inflammation associated with increased local adhesivity. Also, hemorrhagic necrosis and diffuse interstitial extravillous and gigantocellular trophoblast was noticed. The particularity of OEP is represented by the hypervascular and hypercellular villosity structure, unlike the usual hypovascular-hypocellular one [34].

These hypovascular aspects have been reported in some studies and the cause is represented by the lack of spiral maternal artery protrusion through the double layered structure of the villous trophoblast formed by the syncytiotrophoblast and the cytotrophoblast leading to villosity hypoxia associated with hypertension, preeclampsia, intrauterine growth restriction [35]. This aspect may be particular for OEP because the structure of the ovarian arteries is different from the spiral myometrial arteries, the latter presenting an extra tunic, the external tunic and which cannot penetrate intravillous [36].

In the ovarian tissue, the presence of pregnancy corpus luteum and numerous inflammatory periluteal and intraluteal elements were identified. The lymphoplasmocytary cells determine an important locally inflammatory process against the ectopic mass. T-cells or natural killer T-cells can recognize and eliminating ectopic cells with the aid of proinflammatory cytokines [37]. Their activity attracts mastocytes and macrophages. Local B-lymphocytes are activated and are capable of secreting antibodies [38], which will act upon the mass. This is confirmed by the presence of necrosis around the villosities. The local inflammation which appeared as an immune cellular response, increases the number of macrophages and mastocytes leading to an important ovarian inflammation process. This inflammatory process can appear before conception, which represents a risk factor for oocyte nidation at ovarian level $[39,40]$ or it can appear after conception, triggering the activation of cell destruction processes. When neutrophils are not capable anymore of 
controlling the local situation, they lose their function and die, and macrophages dispose of their remains [41]. The high number of macrophages immunolabeling with the anti-CD68 antibody, identified at the ovarian level proves their involvement.

Moreover, the mastocytes immunolabeling with antitryptase antibody, regulate the local inflammatory response, intensifying it, producing a series of chemical compounds like: monokins, interleukin-21 (IL-21), complement proteins which will activated and determine ectopic cell destruction. This entire inflammatory process led to an increased local adhesivity, favoring nidation at this level and, simultaneously, led to the destruction and blockage of normal pregnancy development, rupture and hemoperitoneum [42-44]. There are some resilient macrophages which can provide good growth factors for tissue development which demonstrates the development of up to seven weeks of gestation in an inflammatory environment of this pregnancy [45-47]. The mastocytes activate local angiogenesis and increase vascular permeability through the degranulation process [48-51]. Angiogenesis activation is proved by the high number of intraluteal capillary vessels immunolabeling with anti-CD34 antibody [34].

Another element which can be involved in OEP is represented by the obstructed vessels which determine a lack of perfusion leading to cellular necrosis with accentuated immune response and eventually local periluteal adhesion increase. The patient can have a history of thrombophilia without any ongoing treatment and the presence of vascular thrombosis can be a consequence of this pathology $[52,53]$.

Anti-CK AE1/AE3 antibody specific for epithelial tissue, is composed of a cocktail of CKs 1-8, 10, 14-16 and 19 with the exception of CK17 and CK18 [54]. This antibody compound allowed us to observe the positive granulosa cells with disorganized cytoplasm due to hemorrhagic necrosis and the extravillous extracellular gigantocellular trophoblast. Positive reaction was determined at the intracytoplasmic level of the cytotrophoblast and negative at the syncytiotrophoblast level using the antiCK7 antibody. This positive reaction confirms an OEP [55-57].

Immunolabeling of myofibroblast cell actin from the theca and granulosa zone with the anti- $\alpha$-SMA antibody and the mesenchymal cells from the structure of mesenchymal placental villosities with anti-VIM antibody revealed the high number of these cells [55-57].

Physiologically, after ovulation, the granulosa cells begin to shrink and suffer disintegration processes, pyknosis, accumulation of intracytoplasmic lipids and eventually they will be phagocytized turning into corpus albicans [58].

In some studies, corpus luteum did not have any aspect of disintegration. On the contrary, in had a powerful hormonal load, demonstrated by the reactivity with antiPR antibody, slightly positive at the theca cells, highly positive at the granulosa cells and negative at the mesenchymal placental villosities level. Unlike the PRs, the reactivity for the ERs was negative. The local progesterone effect contributed to the progression of the pregnancy for a decent period of time through maternal immune response and inhibition of local inflammatory response [59].
Ki67 antigen represents a cellular proliferation marker coded in humans by the marker of proliferation Ki-67 (MKI67) gene and identified at tissue level using antiKi67 antibody [58, 59]. Ki67 protein is present in all active phases of cellular cycle but is absent in resting state cells [60].

In OEP, a positive nuclear reaction can be obtained at the cytotrophoblast which proves that villous trophoblastic proliferation takes places at this site and not in the syncytiotrophoblast, where the reaction was negative even though in the second and third trimester of pregnancy only the syncytiotrophoblast persist.

Tumor protein 63 (p63) is coded in the human body by a particular gene, TP63 [60-63] and is part of the tumor protein 53 (p53) family [64]. P63 is a promoter in stem cell regulation [65], and at the placental villosities of OEP it was seen in the cytotrophoblast proliferation areas, similar to Ki67 protein. P53 was not identified in some cases due to the lack of alterations in genomic stability or cellular apoptosis [66].

The anti-BCL2 antibody which binds to a cell apoptosis regulatory protein, gave a positive reaction at the bitrophoblast villosity level, especially in the syncytiotrophoblast, lasting throughout the pregnancy, which demonstrates that the cytotrophoblast will vanish through apoptosis $[67,68]$.

In OEP can be demonstrated the neuroendocrine origin of the interstitial and giantocellular interstitial trophoblast and the granulosa hormonal secreting cells with the aid of the anti-NSE antibody. This antibody emphasizes enolase 2 enzyme, coded in the ENO2 gene [69].

Calretinin is a protein involved in the calcium mediated signaling and is present in the calbindin 2 (CALB2) gene. In the OEP case, the pathologists observed positive reaction from the individual stromal cells, internal luteinized theca cells and negative reaction from the granulosa cells and external theca cells demonstrating the possible mesothelial origin of the positive cells $[70,71]$.

Inhibin represents a protein complex which inhibits follicle-stimulating hormone synthesis [72], however it does not block the gonadotropin-releasing hormone $(\mathrm{GnRH})$ synthesis [73]. This complex is present in the corpus luteum and can represent a marker in fetuses for Down syndrome when its values are abnormal [74] or for ovarian cancer [75-78].

A positive reaction from the theca cells and a negative reaction from the granulosa cells were observed. Usually, granulosa cells are positive, with variations depending on the growth of the follicle, and this factor may be involved in the release blockage of the oocyte and the subsequent intraluteal or periluteal fecundation.

All these intraovarian risk factors have contributed to the implantation of pregnancy at this level and can cause the recurrence of OEP.

\section{a Conclusions}

Through detailed microscopy techniques, classical and special IHC stainings, we managed to highlight all the characteristic changes of the ovarian gestational site. The main differences between ovarian and normal gestational site consisted of accentuated ovarian inflammatory process, numerous vascular changes at ovarian level, including 
thrombotic complications and atypical aspects of placental villi and corpus luteum. The latter modifications were identified by HP examination and were a consequence both of the ovarian implantation and also of the pre-existent local conditions. The different structure of the ovarian arterial walls and the lack of myometrial specific spiral arteries that invade the trophoblast can be diagnostic elements of ectopic pregnancies. The particular aspects of the granulosa cells and of the internal theca, in terms of positivity for certain protein and hormonal markers, may be involved in the blocked release of the oocyte and intraluteal or periluteal fertilization. These particular elements may represent causes of intraovarian fertilization and are supported by clinical elements from the patient's history. Highlighting potential etiological factors offers the possibility of correcting them before obtaining a new pregnancy, with the improvement of fertile prognosis, such factors being involved in various pregnancy complications.

\section{Conflict of interests}

The authors declare that they have no conflict of interests.

\section{Acknowledgments}

Microscopic images have been acquired in the Research Center for Microscopic Morphology and Immunology, University of Medicine and Pharmacy of Craiova, Romania (Manager: Laurenţiu Mogoantă, Professor, MD, PhD).

\section{Authors' contribution}

Anca-Maria Istrate-Ofițeru and Dan Ruican equally contributed to this article.

\section{References}

[1] Lee R, Dupuis C, Chen B, Smith A, Kim YH. Diagnosing ectopic pregnancy in the emergency setting. Ultrasonography, 2018, 37(1):78-87. https://doi.org/10.14366/usg.17044 PMID: 29061036 PMCID: PMC5769947

[2] Begum J, Pallavee P, Samal S. Diagnostic dilemma in ovarian pregnancy: a case series. J Clin Diagn Res, 2015, 9(4):QR01QR03. https://doi.org/10.7860/JCDR/2015/11501.5772 PMID: 26023609 PMCID: PMC4437125

[3] Goldner TE, Lawson HW, Xia Z, Atrash HK. Surveillance for ectopic pregnancy - United States, 1970-1989. MMWR CDC Surveill Summ, 1993, 42(6):73-85. PMID: 8139528

[4] Bouyer J, Coste J, Fernandez H, Pouly JL, Job-Spira N. Sites of ectopic pregnancy: a 10 year population-based study of 1800 cases. Hum Reprod, 2002, 17(12):3224-3230. https:// doi.org/10.1093/humrep/17.12.3224 PMID: 12456628

[5] Fritz MA, Speroff L. Clinical gynecologic endocrinology and infertility. $8^{\text {th }}$ edition, Wolters Kluwer Health, Lippincott Williams \& Wilkins, Philadelphia, 2011, 1409.

[6] Scutiero G, Di Gioia P, Spada A, Greco P. Primary ovarian pregnancy and its management. JSLS, 2012, 16(3):492-494. https://doi.org/10.4293/108680812X13462882736385 PMID: 23318082 PMCID: PMC3535796

[7] Odejinmi F, Rizzuto MI, MacRae R, Olowu O, Hussain M. Diagnosis and laparoscopic management of 12 consecutive cases of ovarian pregnancy and review of literature. J Minim Invasive Gynecol, 2009, 16(3):354-359. https://doi.org/10. 1016/j.jmig.2009.01.002 PMID: 19423068

[8] Shrestha A, Chawla CD, Shrestha RM. Ruptured primary ovarian pregnancy: a rare case report. Kathmandu Univ Med $J$ (KUMJ), 2012, 10(39):76-77. https://doi.org/10.3126/kumj. v10i3.8026 PMID: 23434969

[9] Meşeci E, Güzel Y, Zemheri E, Eser SK, Ozkanlı S, Kumru P A 34-week ovarian pregnancy: case report and review of the literature. J Turk Ger Gynecol Assoc, 2013, 14(4):246-249. https://doi.org/10.5152/jtgga.2013.31391 PMID: 24592116 PMCID: PMC3935532
[10] Marion LL, Meeks GR. Ectopic pregnancy: history, incidence, epidemiology, and risk factors. Clin Obstet Gynecol, 2012, 55(2):376-386. https://doi.org/10.1097/GRF.0b013e318251 6d7b PMID: 22510618

[11] Oliveira FG, Abdelmassih V, Costa AL, Balmaceda JP Abdelmassih S, Abdelmassih R. Rare association of ovarian implantation site for patients with heterotopic and with primary ectopic pregnancies after ICSI and blastocyst transfer. Hum Reprod, 2001, 16(10):2227-2229. https://doi.org/10.1093/hum rep/16.10.2227 PMID: 11574520

[12] Hemminki E, Heinonen PK. Time trends of ectopic pregnancies. Br J Obstet Gynaecol, 1987, 94(4):322-327. https://doi.org/ 10.1111/j.1471-0528.1987.tb03099.x PMID: 3580315

[13] Roy J, Babu AS. Ovarian pregnancy: two case reports. Australas Med J, 2013, 6(8):406-414. https://doi.org/10.4066/ AMJ.2013.1760 PMID: 24039634 PMCID: PMC3767028

[14] Spiegelberg O. Zur Casuistik der Ovarialschwangerschaft. Arch Gynäkol, 1878, 13(1):73-79. https://doi.org/10.1007/BF 01991416

[15] Gray CL, Ruffolo EH. Ovarian pregnancy associated with intrauterine contraceptive devices. Am J Obstet Gynecol, 1978, 132(2):134-139. https://doi.org/10.1016/0002-9378(78)9091 4-6 PMID: 686101

[16] Istrate-Ofiţeru AM, Pirici D, Niculescu M, Berceanu C, Berceanu S, Voicu NL, Piringă GD, Roşu GC, lovan L, Căpitănescu RG, Diţescu D, Sava A, Mogoantă L, Neacşu A. Clinical, morphological and immunohistochemical survey in different types of endometriosis. Rom J Morphol Embryol, 2018, 59(4):1133-1153. PMID: 30845295

[17] Ciortea R, Costin N, Chiroiu B, Mălutan A, Mocan R, Hudacsko A, Gaia A, Bucuri C, Mihu D. Ovarian pregnancy associated with pelvic adhesions. Clujul Med, 2013, 86(1): 77-80. PMID: 26527922 PMCID: PMC4462474

[18] Sandvei R, Sandstad E, Steier JA, Ulstein M. Ovarian pregnancy associated with the intra-uterine contraceptive device. A survey of two decades. Acta Obstet Gynecol Scand, 1987, 66(2):137141. https://doi.org/10.3109/00016348709083035 PMID: 3618138

[19] Hassan S, Arora R, Bhatia K. Primary ovarian pregnancy: case report and review of literature. BMJ Case Rep, 2012, 2012:bcr2012007112. https://doi.org/10.1136/bcr-2012-007112 PMID: 23175011 PMCID: PMC4544088

[20] Raziel A, Schachter M, Mordechai E, Friedler S, Panski M, Ron-El R. Ovarian pregnancy - a 12-year experience of 19 cases in one institution. Eur J Obstet Gynecol Reprod Biol, 2004, 114(1):92-96. https://doi.org/10.1016/j.ejogrb.2003.09. 038 PMID: 15099878

[21] Mehra S, Negi H, Hotchandani M, Khatri I. Rare case of ovarian pregnancy managed with laparascopy. JK Sci, 2003, 5(1):29-30. https://www.jkscience.org/archive/Volume51/Rare \%20Case\%20of\%20Ovarian\%20Pregnancy.pdf

[22] Joseph RJ, Irvine LM. Ovarian ectopic pregnancy: aetiology, diagnosis, and challenges in surgical management. J Obstet Gynaecol, 2012, 32(5):472-474. https://doi.org/10.3109/014 43615.2012.673039 PMID: 22663322

[23] Levine D. Ectopic pregnancy. Radiology, 2007, 245(2):385-397. https://doi.org/10.1148/radiol.2452061031 PMID: 17940301

[24] Patel Y, Wanyonyi SZ, Rana FS. Laparoscopic management of an ovarian ectopic pregnancy: case report. East Afr Med J, 2008, 85(4):201-204. https://doi.org/10.4314/eamj.v85i4.9645 PMID: 18700354

[25] Comstock C, Huston K, Lee W. The ultrasonographic appearance of ovarian ectopic pregnancies. Obstet Gynecol, 2005, 105(1): 42-45. https://doi.org/10.1097/01.AOG.0000148271.27446.30 PMID: 15625140

[26] Di Luigi G, Patacchiola F, La Posta V, Bonitatibus A, Ruggeri G, Carta G. Early ovarian pregnancy diagnosed by ultrasound and successfully treated with multidose methotrexate. A case report. Clin Exp Obstet Gynecol, 2012, 39(3):390-393. PMID: 23157054

[27] Nadarajah S, Sim LN, Loh SF. Laparoscopic management of an ovarian pregnancy. Singapore Med J, 2002, 43(2):095-096. PMID: 11993898

[28] Jha S, Bosworth K, Quadri A, Ibrahim A. Ovarian ectopic pregnancy. BMJ Case Rep, 2011, 2011:bcr0820103250. https:// doi.org/10.1136/bcr.08.2010.3250 PMID: 22674594 PMCID: PMC3229317

[29] Cunningham FG, Leveno KJ, Bloom SL, Hauth JC, Rouse DJ, Spong CY. Ectopic pregnancy. In: Cunningham FG, Leveno KJ, 
Bloom SL, Hauth JC, Rouse DJ, Spong CY. Williams obstetrics. $23^{\text {rd }}$ edition, Mc Graw-Hill Professional Publishing, New York, USA, 2010, 251.

[30] Stein MW, Ricci ZJ, Novak L, Roberts JH, Koenigsberg M. Sonographic comparison of the tubal ring of ectopic pregnancy with the corpus luteum. J Ultrasound Med, 2004, 23(1):57-62. https://doi.org/10.7863/jum.2004.23.1.57 PMID: 14756354

[31] Boronow RC, McElin TW, West RH, Buckingham JC. Ovarian pregnancy; report of four cases and a thirteen-year survey of the English literature. Am J Obstet Gynecol, 1965, 91(8):10951106. PMID: 14280160

[32] Juan YC, Wang PH, Chen CH, Ma PC, Liu WM. Successful treatment of ovarian pregnancy with laparoscopy-assisted local injection of etoposide. Fertil Steril, 2008, 90(4):1200.e11200.e2. https://doi.org/10.1016/j.fertnstert.2007.11.051 PMID: 18462728

[33] Ghasemi Tehrani H, Hamoush Z, Ghasemi M, Hashemi L. Ovarian ectopic pregnancy: a rare case. Iran J Reprod Med, 2014, 12(4):281-284. PMID: 24976824 PMCID: PMC4071634

[34] Wojciech P. Ross Histologie - Tratat şi atlas. Corelaţii din biologia moleculară şi celulară. $7^{\text {th }}$ edition, Editors: Hinescu M, Borda A, Căruntu ID, Mogoantă L, Raica M, Wolters-Kluwer, Ed. Hipocrate, Romania, 2020, 858-863 (in Romanian).

[35] Huisman MA, Timmer B, Stegehuis J, Swart B, Aarnoudse JG Erwich JHM. Vascularization in first-trimester chorionic villi in complicated and uncomplicated pregnancies. Am J Obstet Gynecol, 2010, 202(1):88.e1-88.e7. https://doi.org/10.1016/ j.ajog.2009.08.036 PMID: 19846051

[36] Crumbie L, Mytilinaios D. Blood vessel histology. Kenhub, last reviewed: November 13, 2020. https://www.kenhub.com/en/ library/anatomy/histology-of-the-vascular-network

[37] Mallevaey T, Fontaine J, Breuilh L, Paget C, Castro-Keller A, Vendeville C, Capron M, Leite-de-Moraes M, Trottein F, Faveeuw C. Invariant and noninvariant natural killer T cells exert opposite regulatory functions on the immune response during murine schistosomiasis. Infect Immun, 2007, 75(5):21712180. https://doi.org/10.1128/IAI.01178-06 PMID: 17353286 PMCID: PMC1865739

[38] Murphy KM. Janeway's Immunobiology. $8^{\text {th }}$ edition, Garland Science, Taylor \& Francis Group, London-New York, 2012.

[39] Ercal T, Cinar O, Mumcu A, Lacin S, Ozer E. Ovarian pregnancy; relationship to an intrauterine device. Aust N Z J Obstet Gynaecol, 1997, 37(3):362-364. https://doi.org/10.1111/j.14 79-828x.1997.tb02434.x PMID: 9325530

[40] Helde MD, Campbell JS, Himaya A, Nuyens AJ, Cowley FC, Hurteau GD. Detection of unsuspected ovarian pregnancy by wedge resection. Can Med Assoc J, 1972, 106(3):237-242. PMID: 5057958 PMCID: PMC1940374

[41] Eming SA, Krieg T, Davidson JM. Inflammation in wound repair: molecular and cellular mechanisms. J Invest Dermatol, 2007 127(3):514-525. https://doi.org/10.1038/sj.jid.5700701 PMID: 17299434

[42] Chen $Y$, Zhang $X$. Pivotal regulators of tissue homeostasis and cancer: macrophages. Exp Hematol Oncol, 2017, 6:23. https://doi.org/10.1186/s40164-017-0083-4 PMID: 28804688 PMCID: PMC5549331

[43] Goto H, das Graças Prianti M. Immunoactivation and immunopathogeny during active visceral leishmaniasis. Rev Inst Med Trop Sao Paulo, 2009, 51(5):241-246. https://doi.org/10. 1590/s0036-46652009000500002 PMID: 19893975

[44] Matzaraki V, Kumar V, Wijmenga C, Zhernakova A. The MHC locus and genetic susceptibility to autoimmune and infectious diseases. Genome Biol, 2017, 18(1):76. https://doi.org/10. 1186/s13059-017-1207-1 PMID: 28449694 PMCID: PMC 5406920

[45] Vlahopoulos SA. Aberrant control of NF- $k B$ in cancer permits transcriptional and phenotypic plasticity, to curtail dependence on host tissue: molecular mode. Cancer Biol Med, 2017, 14(3):254-270. https://doi.org/10.20892/j.issn.2095-3941.2017. 0029 PMID: 28884042 PMCID: PMC5570602

[46] Okabe Y, Medzhitov R. Tissue-specific signals control reversible program of localization and functional polarization of macrophages. Cell, 2014, 157(4):832-844. https://doi.org/10.1016/ j.cell.2014.04.016 PMID: 24792964 PMCID: PMC4137874

[47] Gosselin D, Link VM, Romanoski CE, Fonseca GJ, Eichenfield DZ, Spann NJ, Stender JD, Chun HB, Garner H, Geissmann F, Glass CK. Environment drives selection and function of enhancers controlling tissue-specific macrophage identities. Cell, 2014, 159(6):1327-1340. https://doi.org/10. 1016/j.cell.2014.11.023 PMID: 25480297 PMCID: PMC4364385

[48] Muller PA, Koscsó B, Rajani GM, Stevanovic K, Berres ML, Hashimoto D, Mortha A, Leboeuf M, Li XM, Mucida D, Stanley ER, Dahan S, Margolis KG, Gershon MD, Merad M, Bogunovic M. Crosstalk between muscularis macrophages and enteric neurons regulates gastrointestinal motility. Cell, 2014, 158(2):300-313. https://doi.org/10.1016/j.cell.2014.04.050 PMID: 25036630 PMCID: PMC4149228

[49] Uderhardt S, Martins AJ, Tsang JS, Lämmermann T, Germain RN Resident macrophages cloak tissue microlesions to prevent neutrophil-driven inflammatory damage. Cell, 2019, 177(3): 541-555.e17. https://doi.org/10.1016/j.cell.2019.02.028 PMID: 30955887 PMCID: PMC6474841

[50] da Silva EZM, Jamur MC, Oliver C. Mast cell function: a new vision of an old cell. J Histochem Cytochem, 2014, 62(10): 698-738. https://doi.org/10.1369/0022155414545334 PMID: 25062998 PMCID: PMC4230976

[51] Moon TC, Befus AD, Kulka M. Mast cell mediators: their differential release and the secretory pathways involved. Front Immunol, 2014, 5:569. https://doi.org/10.3389/fimmu.2014. 00569 PMID: 25452755 PMCID: PMC4231949

[52] Polyzoidis S, Koletsa T, Panagiotidou S, Ashkan K, Theoharides TC. Mast cells in meningiomas and brain inflammation. J Neuroinflammation, 2015, 12(1):170 https://doi.org/10.1186/ s12974-015-0388-3 PMID: 26377554 PMCID: PMC4573939

[53] Heit JA. Thrombophilia: common questions on laboratory assessment and management. Hematology Am Soc Hematol Educ Program, 2007, 127-135. https://doi.org/10.1182/ash education-2007.1.127 PMID: 18024620

[54] Baglin T, Gray E, Greaves M, Hunt BJ, Keeling D, Machin S, Mackie I, Makris M, Nokes T, Perry D, Tait RC, Walker I, Watson H; British Committee for Standards in Haematology. Clinical guidelines for testing for heritable thrombophilia. $\mathrm{Br} J$ Haematol, 2010, 149(2):209-220. https://doi.org/10.1111/j. 1365-2141.2009.08022.x PMID: 20128794

[55] Pernick N. Stains \& molecular markers. Cytokeratin AE1 / AE3. PathologyOutlines.com, topic completed: 1 July 2013, minor changes: 10 March 2021. https://www.pathologyoutlines.com/ topic/stainsae1ae3.html

[56] Benjamin E, Law S, Bobrow LG. Intermediate filaments cytokeratin and vimentin in ovarian sex cord-stromal tumours with correlative studies in adult and fetal ovaries. J Pathol, 1987, 152(4):253-263. https://doi.org/10.1002/path.1711520 403 PMID: 2444685

[57] Czernobilsky B, Moll R, Levy R, Franke WW. Co-expression of cytokeratin and vimentin filaments in mesothelial, granulosa and rete ovarii cells of the human ovary. Eur J Cell Biol, 1985, 37:175-190. PMID: 3896804

[58] Miettinen M, Lehto VP, Virtanen I. Expression of intermediate filaments in normal ovaries and ovarian epithelial, sex cordstromal, and germinal tumors. Int J Gynecol Pathol, 1983, 2(1):64-71. https://doi.org/10.1097/00004347-198301000-00 006 PMID: 6307907

[59] Adams EC, Hertig AT. Studies on the human corpus luteum. I. Observations on the ultrastructure of development and regression of the luteal cells during the menstrual cycle. J Cell Biol, 1969, 41(3):696-715. https://doi.org/10.1083/jcb. 41.3.696 PMID: 5768870 PMCID: PMC2107822

[60] Bullwinkel J, Baron-Lühr B, Lüdemann A, Wohlenberg C, Gerdes J, Scholzen T. Ki-67 protein is associated with ribosomal RNA transcription in quiescent and proliferating cells. J Cell Physiol, 2006, 206(3):624-635. https://doi.org/10.1002/jcp. 20494 PMID: 16206250

[61] Schonk DM, Kuijpers HJ, van Drunen E, van Dalen CH, Geurts van Kessel AH, Verheijen R, Ramaekers FC. Assignment of the gene(s) involved in the expression of the proliferationrelated Ki-67 antigen to human chromosome 10 . Hum Genet, 1989, 83(3):297-299. https://doi.org/10.1007/BF00285178 PMID: 2571566

[62] Bruno S, Darzynkiewicz Z. Cell cycle dependent expression and stability of the nuclear protein detected by Ki-67 antibody in HL-60 cells. Cell Prolif, 1992, 25(1):31-40. https://doi.org/ 10.1111/j.1365-2184.1992.tb01435.x PMID: 1540682

[63] Yang A, Kaghad M, Wang Y, Gillett E, Fleming MD, Dötsch V, Andrews NC, Caput D, McKeon F. p63, a p53 homolog at $3 q 27-29$, encodes multiple products with transactivating, deathinducing, and dominant-negative activities. Mol Cell, 1998, 
2(3):305-316. https://doi.org/10.1016/s1097-2765(00)80275-0 PMID: 9774969

[64] Tan M, Bian J, Guan K, Sun Y. p53CP is $p 51 / p 63$, the third member of the $p 53$ gene family: partial purification and characterization. Carcinogenesis, 2001, 22(2):295-300. https:// doi.org/10.1093/carcin/22.2.295 PMID: 11181451

[65] Wu G, Nomoto S, Hoque MO, Dracheva T, Osada M, Lee CC Dong SM, Guo Z, Benoit N, Cohen Y, Rechthand P, Califano J, Moon CS, Ratovitski E, Jen J, Sidransky D, Trink B. $\triangle$ Np63a and TAp63 $\alpha$ regulate transcription of genes with distinct biological functions in cancer and development. Cancer Res, 2003, 63(10):2351-2357. PMID: 12750249

[66] Crum CP, McKeon FD. p63 in epithelial survival, germ cell surveillance, and neoplasia. Annu Rev Pathol, 2010, 5:349 371. https://doi.org/10.1146/annurev-pathol-121808-102117 PMID: 20078223

[67] Han ES, Muller FL, Pérez VI, Qi W, Liang H, Xi L, Fu C, Doyle E, Hickey M, Cornell J, Epstein CJ, Roberts LJ, Van Remmen H, Richardson A. The in vivo gene expression signature of oxidative stress. Physiol Genomics, 2008, 34(1):112-126. https://doi.org/10.1152/physiolgenomics.00239.2007 PMID: 18445702 PMCID: PMC2532791

[68] Tsujimoto Y, Finger LR, Yunis J, Nowell PC, Croce CM. Cloning of the chromosome breakpoint of neoplastic B cells with the $t(14 ; 18)$ chromosome translocation. Science, 1984 , 226(4678):1097-1099. https://doi.org/10.1126/science.6093 263 PMID: 6093263

[69] Cleary ML, Smith SD, Sklar J. Cloning and structural analysis of cDNAs for bcl-2 and a hybrid bcl-2/immunoglobulin transcript resulting from the $t(14 ; 18)$ translocation. Cell, 1986, 47(1): 19-28. https://doi.org/10.1016/0092-8674(86)90362-4 PMID: 2875799

[70] Oliva D, Calì L, Feo S, Giallongo A. Complete structure of the human gene encoding neuron-specific enolase. Genomics, 1991, 10(1):157-165. https://doi.org/10.1016/0888-7543(91) 90496-2 PMID: 2045099

[71] Rogers JH. Calretinin: a gene for a novel calcium-binding protein expressed principally in neurons. J Cell Biol, 1987,
105(3):1343-1353. https://doi.org/10.1083/jcb.105.3.1343 PMID: 3654755 PMCID: PMC2114790

[72] Parmentier M, Passage E, Vassart G, Mattei MG. The human calbindin D28k (CALB1) and calretinin (CALB2) genes are located at 8q21.3----q22.1 and 16q22----q23, respectively, suggesting a common duplication with the carbonic anhydrase isozyme loci. Cytogenet Cell Genet, 1991, 57(1):41-43. https:// doi.org/10.1159/000133111 PMID: 1906795

[73] van Zonneveld P, Scheffer GJ, Broekmans FJ, Blankenstein MA, de Jong FH, Looman CW, Habbema JD, te Velde ER. Do cycle disturbances explain the age-related decline of female fertility? Cycle characteristics of women aged over 40 years compared with a reference population of young women. Hum Reprod, 2003, 18(3):495-501. https://doi.org/10.1093/humrep/ deg138 PMID: 12615813

[74] Luisi S, Florio P, Reis FM, Petraglia F. Inhibins in female and male reproductive physiology: role in gametogenesis, conception, implantation and early pregnancy. Hum Reprod Update, 2005, 11(2):123-135. https://doi.org/10.1093/humupd/dmh057 PMID: 15618291

[75] Aitken DA, Wallace EM, Crossley JA, Swanston IA, van Pareren Y, van Maarle M, Groome NP, Macri JN, Connor JM. Dimeric inhibin A as a marker for Down's syndrome in early pregnancy. N Engl J Med, 1996, 334(19):1231-1236. https:// doi.org/10.1056/NEJM199605093341904 PMID: 8606718

[76] Robertson DM, Pruysers E, Jobling T. Inhibin as a diagnostic marker for ovarian cancer. Cancer Lett, 2007, 249(1):14-17. https://doi.org/10.1016/j.canlet.2006.12.017 PMID: 17320281

[77] Robertson DM, Pruysers E, Burger HG, Jobling T, McNeilage J, Healy D. Inhibins and ovarian cancer. Mol Cell Endocrinol, 2004, 225(1-2):65-71. https://doi.org/10.1016/j.mce.2004.02. 014 PMID: 15451569

[78] Visfeldt J, Starup J. Histology of the human corpus luteum of early and late pregnancy. Acta Pathol Microbiol Scand A, 1975, 83(6):669-677. https://doi.org/10.1111/j.1699-0463.1975. tb01396.x PMID: 171912

\section{Corresponding authors}

George Lucian Zorilă, Teaching Assistant, MD, PhD, Department of Obstetrics and Gynecology, University of Medicine and Pharmacy of Craiova, 2 Petru Rareş Street, 200349 Craiova, Dolj County, Romania; Phone +40741-236 305, e-mail: zorilalucian@gmail.com

Gabriela-Camelia Roşu, Teaching Assistant, MD, PhD, Department of Histology, University of Medicine and Pharmacy of Craiova, 2 Petru Rareş Street, 200349 Craiova, Dolj County, Romania; Phone +40766-313 097, e-mail: nicola_camelia92@yahoo.com

Received: January 30, 2021

Accepted: May 27, 2021 